Kong. Res. J. 2(1) : 97-101, 2015

ISSN 2349-2694

Kongunadu Arts and Science College, Coimbatore.

\title{
IN VITRO CALLUS INDUCTION OF SMILAX WIGHTII A.DC AN ENDEMIC MEDICINAL PLANT
}

\author{
Nantha kumar, R*., H. Abdul kaffoor, K. Arumugasamy, A. Shalimol and V. Asha devi \\ PG and Research Department of Botany, Kongunadu Arts and Science College, Coimbatore-641029. \\ *E.mail: nanthabio@gmail.com
}

\begin{abstract}
\end{abstract}
Smilax wightii A.DC is an endemic medicinal plant belongs to the family smilacaceae and distributed in Kodanadu, The Nilgiri Hills, The Western Ghats, Southern India. The callus was obtained at the concentration of $1.5+0.05 \mathrm{mg} / \mathrm{I} \mathrm{TDZ}$ with NAA. Highest number of shoots was observed in $2.0+0.04 \mathrm{mg} / \mathrm{l}$ BAP $+\mathrm{Kn}$ and followed by $2.0+0.04 \mathrm{mg} / \mathrm{l}$. The multiplied shoots were harvested and used for rooting on half strength MS medium containing indole-3-butyric acid and naphthalene acetic acid within 45 days. The best rooting response was achieved on half-strength MS medium supplemented with $2.0 \mathrm{mg} / \mathrm{l}$ IBA. The well rooted plantlets were acclimatized and successfully transferred to natural condition, where $85 \%$ plantlets were survived.

Key words: Callus, endemic medicinal plant, Smilax wightii.

\section{INTRODUCTION}

Plant tissue culture is the technique of growing plant cells, tissues and organs in an artificially prepared nutrient medium static or liquid, under asceptic conditions. Tissue culture is used for conservation of biological diversity by multiplication of plant species that have extremely small populations, for species with restricted reproductive capabilities and for recovery and reintroduction (Bramwell, 1990). The main areas of research in plant tissue culture viz. micropropagation, anther and microspore culture, somaclonal variations and mutagenesis, protoplast culture and somatic hybridization are some of the effective tools for regeneration and conservation of endangered plants (Bapat et al., 2008).

Smilacaceae comprises of 10 genera with more than 300 species, found on temperature zones, tropic and subtropics worldwide (Fnaec, 2002). Smilax wightii A.DC. is a rare endemic generally distributed in Shola forests at high altitudes in Nilgiri Biosphere Reserve, the Western Ghats, Southern India.The roots of $S$. wightii have been reported to cure dysentery, amoebiasis, veneral diseases, leucorrhoea, urinary complaints, fever, spermatorrhoea, antifertility, anaemia, rheumaticarthritis, veterinary amoebiasis and gastric complaints (Adhikari et al., 2010).

\section{MATERIALS AND METHODS}

\subsection{Collection of plant material}

The whole plant Smilax wightii was collected from Kodanadu, The Nilgiri Hills, The Western Ghats, Southern India, Tamil Nadu. The plant was identified and authenticated by a plant taxonomist, Coimbatore.

\subsection{In vitro study}

\subsubsection{Explant sources}

The fresh leaf samples of $S$. wightii was collected from its original habitat, and maintained in green house condition and one year old young, healthy, disease free leaves were used as explants, sources.

\subsubsection{Explant sterilization}

Freshly excised leaf explants of $S$. wightii was surface sterilized and washed in tap water for 2-5 minutes, and again rewashed with liquid detergent (Rankleen, Ranbaxy India) and Tween 20 (Himedia Laboratories, India) for 2-5 minutes with vigorous shaking. These explants were again washed with running tap water to remove any traces of detergent and kept in $1 \%(\mathrm{w} / \mathrm{w})$ solution of Bavistin (BASP India Limited) for one hour and transferred to $1 \%$ (v/v) Savlon (Johnson and Johnson, USA) for 1-2 minutes. In the laminar hood there washed again 2-3 times with sterile distilled water. All these explants were taken and dipped in 70\% ethyl alcohol for 30 seconds, surface sterilized with freshly prepared $0.1 \%(\mathrm{w} / \mathrm{v})$ aqueous solution of mercuric chloride for 20-30 seconds and thoroughly washed with 3-4 times with sterile water and removed all traces of mercuric chloride.

\subsubsection{Culture media}

The basal medium used for the culture is Murashige and Skoog medium with sucrose 3\% (Analytical grade, Himedia, India) and $0.8 \%$ agar (Bacteriological grade, Himedia, India) was used the 
composition of this medium consist of growth homones, 6 -benzylamino purine (BA), Thiadiazuron (TDZ), 3 -Indole butyric acid (IBA), Kinetin (Kn), adenine sulphate were added to the basal medium either singly or in various combinations. Cytokinins were dissolved first with the respective acidic solution (1N $\mathrm{NHcl}$ ) and auxins in few drops of basic solutions $(1 \mathrm{NKOH})$. The final volume was made up with distilled water and kept in refrigeration. (Growth regulators are from Sigma, USA). Generally, after adding all the ingredients in required amounts, the final volume was made up with distilled water. The $\mathrm{pH}$ of the medium was adjusted to 5.8 by using $1 \mathrm{~N} \mathrm{KOH}$ or $1 \mathrm{NHcl}$ (Cyber scan 510, Eutech Instruments, Singapore), agar (Himedia Labs Limited, India) added to the medium at the rate of $0.8 \%(\mathrm{w} / \mathrm{v})$ for solidification of the medium, The media ( $50 \mathrm{ml} / 300 \mathrm{ml}$ bottle) were transferred in to the bottles which were tightly capped and labelled properly in to the media was autoclaved (Equitron, Medical Instuments, India) at $121^{\circ} \mathrm{C}$ for 20 minutes at 15 psi.

\subsubsection{Inoculation of the explants}

All the explants were sterilized, trimmed and inoculated in culture bottles aseptically and transferred to culture tubes with the help of sterile forceps under strict aseptic conditions. The mouths of the tubes were quickly flamed and culture tubes tightly capped and the mouth of the tubes were properly sealed with cotton plug to avoid entry of external air. All the tubes were properly labelled and transferred to aseptic culture room.

\subsubsection{Culture conditions}

All cultures were incubated and maintained under 16 hours photoperiod with light intensity of 2000-2500 luX (PolyluX XL, GE Britain, $36 \mathrm{~W}$ and temperature of $25 \pm 10^{\circ} \mathrm{C}$ ).

\section{RESULTS}

An In vitro propogation method has been developed for $S$. wightii, an endemic medicinal plant from Kodanadu, the Nilgiri Hills, In the present study, the leaf explants of $S$. wightii were excised from their natural habitat and maintained in green house were cultured on MS basal medium supplemented with various concentrations of BA, TDZ and 2,4-D and combinations of NAA with BA, NAA with 2,4-D and NAA with 2,4-D at various concentrations for the induction of callus.

\subsection{Callus proliferation}

The leaf explants were cultured on MS basal medium supplemented with BA, 2-4D and TDZ with regulators separately in different concentrations
$(0.1,0.5,1.5$ and $2.0 \mathrm{mg} / \mathrm{L})$ and NAA with a concentration of $0.05 \mathrm{mg} / \mathrm{L}$ was combined with BA, 2,4-D and TDZ at different concentrations $(0.1,0.5,1.5$ and $2.0 \mathrm{mg} / \mathrm{L})$. In the above combinations callus formation from leaf explants were achieved by using MS medium supplemented with BA (2.0 mg/L), TDZ with $(2.0 \mathrm{mg} / \mathrm{L})$, NAA with BA $(0.05+2.0)$, NAA with $2,4-\mathrm{D}(0.05+2.0)$ and NAA with TDZ $(0.05+2.0)$ respectively (Table-1).

The callus formation was observed on MS basal medium with TDZ in the concentration of $2.0 \mathrm{mg} / \mathrm{L}$ with respect to $73 \%$ in leaf explants. MS medium with TDZ + NAA combinations $(1.5+0.05 \mathrm{mg} / \mathrm{L})$ showed $83 \%$ callus formation. BA and NAA in the concentration of $1.5+0.05$ (mg/L) developed $74 \%$ callus formation. Among these concentrations of growth regulators, maximum callus formation for leaf explant was observed on MS basal medium with TDZ+NAA $(1.5+0.05 \mathrm{mg} / \mathrm{mL})$ (Table- 2). It was observed that leaf explants cultured in the basal medium containing 2,4-D appeared to be white green coloured and friable callus. The BA, BA in combination with NAA, and TDZ, TDZ in combination with NAA developed light green coloured and compact callus. Crystallized callus mass which turned to hard, compact green solid mass of callus growth within 20-27 days (Table- 2).

\section{DISCUSSION}

Plant tissue culture techniques enable high efficiency and quick production of ethic and pathogens-free plants besides provoke a considerable interest as a potential alternative to produce bioactive compounds. Plant growth regulators are fundamental to integrate and regulate plant development and their addition in culture media have been widely employed to improve morphogenesis and plant development. In vitro propagation techniques offer an option for the conservation of rare, threatened and endangered medicinal plants (Mallon et al., 2010). These techniques used for rapid and large-scale propagation of medicinal, aromatic, crop, ornamental plants and for the isolation and enhancement of more medicinal secondary products (Sahooy et al., 1997). Plant tissue culture production of medicinal plants offers a number of unique advantages like possibility of year-round continuous production of phytochemicals under controlled conditions (Kayser and Quax, 2007).

The present study is described the in vitro regeneration of an endemic medicinal plant, Smilax wightii of Smilacaceae from the leaf explants. These explants were cultured on MS basal medium supplemented with various concentrations of, BA 
TDZ, 2,4- D and with combinations of NAA, for the induction of callus and subsequent development of plantlets. MS medium has showed the highest percentage and dry weight of the callus in S. wightii. Khatun et al. (2003) have reported that MS was the most suitable media for callus induction. S. tetrandra grown on different basal salt media developed maximum callogenesis with one fold MS media. Addition of peptone into MS the culture medium has strongly improved the growth of tobacco callus. In the study, the addition of peptone $(2 \mathrm{~g} / \mathrm{L})$ has promoted callus growth. Because peptides could be more efficient source of nitrogen for sustaining in vitro callus proliferation. The texture of callus varied according to the nature of cytokinin and also on auxin and cytokinin ratio (Martin, 2002). Morphological and phytochemical differences in callus are attributing to culture conditions, composition of the medium orientation of the explants, and growth and morphogenesis ability of plants itself. Various types and concentration of hormones present in medium directly affect the nature, colour and biochemical composition of callus (Skoog and Miller, 1967).

It may be explained that the specific growth hormones at appropriate concentrations can play major role to induce callus besides the other factors (Ananthi et al., 2011). Baskar and Jayabalan (2005) suggested that the differential response of same or different explants for callus formation could be due to the nature of tissue, degree of totipotency and composition of medium with respect to micronutrients and hormones. Further, it is explained that the variation in response of leaf discs in terms of callus formation may be due to the variation in distribution of endogenous level of growth regulators as observed in plants (Farternale et al., 2002). The present results of $S$. wightii leaf explants indicated that individual growth regulators are not developed any organs or callus induction. However, several combinations of growth regulators have shown to induce the formation of callus. The young moderate sized leaf explants were well responded for rapid callogenesis after incubation period of 4 weeks. A pale green colour and healthy compact calli were observed on first week of inoculation at the trimmed regions on MS media supplemented with $1.5 \mathrm{mg} / \mathrm{l}$ TDZ concentrations. The highest callus fresh weight was obtained in the medium containing $1.5 \mathrm{mg} / \mathrm{l} \mathrm{TDZ}+0.02 \mathrm{mg} / \mathrm{l} \mathrm{NAA}$ combinations.

Variations in the callus forming ability of different explant types have reported in many plants. Callus from leaf segments showed initiation of vigorous, proliferating, soft and green colored tissue
(Chand and Roy, 1980). TDZ, a synthetic phenylurea is considered to be one of the most active cytokinins for callus and shoot induction in plant tissue culture. TDZ-induced callus induction from different explants of many recalcitrant species as well as from medicinal plants has been reported. Several reports suggest that TDZ results in callus induction better than other cytokinins.

Aditi Singh et al. (2009) have explained callus formation in Tinospora cordifolia developed from nodal, inter-nodal and leaf explants when planted on the MS medium containing the combination of BAP and NAA. Of these, callusing response was seen only on leaf explants study have showed a combination of 2,4-D, BAP and Kin $(2.0,2.0$ and $1.0 \mu \mathrm{M})$ in MS medium enhances the callus production in Coscinium fenestratum. Our results are similar to Kuo et al. (2005) investigations, where an efficient in vitro callus induction system in $S$. Wightii was established on MS medium supplemented with 3\% sucrose and different concentrations of plant growth regulators i.e. auxins (2,4-D, IAA and NAA) and cytokinins (BA, kinetin, TDZ and zeatin) in the dark. MS medium supplemented with $1.0 \mathrm{mg} / \mathrm{L} \mathrm{BA}$ and $0.5 \mathrm{mg} / \mathrm{L} \mathrm{TDZ}$ supported callus growth and its proliferation. A maximum amount of dry biomass (7.8 fold) was produced 45 days after culture. Similarly in Taxus wallichiana the stem explants developed brown friable callus in different basal media, supplemented with $2 \mathrm{mg} / \mathrm{l}$ of 2,4-D. Callus induction was found to be best in MS media solidified with $10 \mathrm{~g} / \mathrm{l}$ agar and supplemented with $1-5 \mathrm{mg} / \mathrm{l}$ NAA. Further, addition of kinetin $(1-5 \mathrm{mg} / \mathrm{l})$ has resulted in more active callus formation. The colour of calluses ranged from brown to green, greenish yellow and yellow.

Callus potential has reported to vary from species to species and often differs in varieties of same species (Pradeep Kumar and RanjithaKumari, 2010). Karappusamy and Pullaiah (2007) have reported an effective callus formation from the leaf explant in the medium containing high quantity of NAA for Bupleurum distichophyllum. Mariani et al. (2011) have suggested the requirement of the cytokinin like compounds, TDZ for callus formation in Aglaonema spp. The cytokinin is known major growth hormone involved in shoot formation of plant species (Sujatha et al., 2008).

The highest number of shoots from leaf explants of $S$. wightii were observed in TDZ+NAA $(1.5+0.03$ and $2.0+0.04 \mathrm{mg} / \mathrm{l})$ and followed by $2.0+0.04 \mathrm{mg} / \mathrm{l}$ of $\mathrm{BA}+\mathrm{NAA}$ combinations when the callus cultured in MS medium. The regeneration frequency was high in TDZ and BA combined with NAA. These results were similar to Kannan et al. 
(2007) who have established an in vitro propagation of Excaum travancoricum. The internodal explant of E. travancoricum was cultured on MS with different levels of Thidiazuron or BA showed gradual bulging. They have observed the direct shoot morphogenesis on the cut ends of the explants cultured on MS medium with TDZ or BA. Here, TDZ was superior to BA in the induction and proliferation of shoots. The shoots induced on TDZ enriched medium were healthier than the shoots raised on BAP. Culture of shoot clumps on MS medium having TDZ favoured proliferation of shoots. The high efficient of TDZ over BA has been documented in several woody plants (Vidya et al., 2005).

Table 1. Effect of different concentrations of plant growth regulators on callus induction from leaf explants of Smilax wightii.

\begin{tabular}{|c|c|c|c|c|}
\hline \multirow[b]{2}{*}{$\begin{array}{l}\text { Plant growth } \\
\text { regulators }\end{array}$} & \multirow{2}{*}{$\begin{array}{l}\text { Concentration of plant } \\
\text { growth regulators } \\
\mathrm{mg} / \mathrm{L}\end{array}$} & \multirow[b]{2}{*}{$\begin{array}{l}\text { Intensity of callus } \\
\text { formation }\end{array}$} & \multicolumn{2}{|l|}{ Leaf explant } \\
\hline & & & $\begin{array}{c}\text { Mean callus weight } \pm \\
\text { SD }\end{array}$ & Nature of callus \\
\hline \multirow[t]{2}{*}{ Control } & -- & -- & -- & -- \\
\hline & 0.1 & + & 0 & No callus formed \\
\hline \multirow{4}{*}{ RA } & 0.5 & + & $0.32 \pm 0.03$ & White green friable \\
\hline & 1.5 & + & $0.45 \pm 0.17$ & White green, friable \\
\hline & 2.0 & ++ & $0.74 \pm 0.26$ & Light green, compact \\
\hline & 0.1 & + & $0.33 \pm 0.12$ & White green friable \\
\hline \multirow[t]{4}{*}{ TDZ } & & + & $0.49 \pm 0.23$ & White green, friable \\
\hline & 1.5 & + & $0.68 \pm 0.06$ & White green, friable \\
\hline & 2.0 & ++ & $0.85 \pm 0.34$ & Light green, compact \\
\hline & 0.1 & -- & 0 & No callus formed \\
\hline \multirow{4}{*}{$2,4-\mathrm{D}$} & v.u & + & $25 \pm 0.11$ & White green, friable \\
\hline & 1.5 & + & $0.32 \pm 0.23$ & White green, friable \\
\hline & 2.0 & ++ & $0.38 \pm 0.04$ & White green, friable \\
\hline & $0.1+0.05$ & -- & 0 & No callus formed \\
\hline \multirow{4}{*}{$\mathrm{RA}+\mathrm{NAA}$} & $0.5+0.05$ & + & $0.34 \pm 0.16$ & White green, friable \\
\hline & $1.5+0.05$ & + & $0.51 \pm 0.32$ & White green, friable \\
\hline & $2.0+0.05$ & ++ & $0.87 \pm 0.26$ & Light green, compact \\
\hline & $0.1+0.05$ & -- & 0 & No callus formed \\
\hline \multirow[t]{4}{*}{ 2,4-D + NAA } & & + & $0.27 \pm 0.41$ & White green, friable \\
\hline & $1.5+0.05$ & + & $0.39 \pm 0.17$ & White green, friable \\
\hline & $2.0+0.05$ & + & $0.42 \pm 0.08$ & White green, friable \\
\hline & $0.1+0.05$ & + & $0.76 \pm 0.12$ & White green, friable \\
\hline \multirow{3}{*}{ Tn7 + N $\Delta \Delta$} & $0.5+0.05$ & + & $0.84 \pm 0.23$ & White green, friable \\
\hline & $1.5+0.05$ & + & $0.92 \pm 0.08$ & Light green, compact \\
\hline & $2.0+0.05$ & +++ & $1.42 \pm 0.22$ & Light green, compact \\
\hline \multicolumn{5}{|c|}{$\begin{array}{l}\text { Intensity of callus: }(+) \text { low; }(++) \text { moderate; }(+++) \text { high. } \\
\text { Values are expressed as Mean } \pm \text { Standard Error of } 3 \text { replicates. Means within a column followed by a common letter aren't signi ficantly } \\
\text { different at } 5 \% \text { level by SPSS. }\end{array}$} \\
\hline $\begin{array}{l}\text { Plant growth } \\
\text { regulators }\end{array}$ & $\begin{array}{l}\text { Concentration of } \\
\text { growth } \\
\text { regulators } \\
\text { mg/L }\end{array}$ & Days requ & $\begin{array}{l}\text { for callus formation after } \\
\text { inoculation }\end{array}$ & $\begin{array}{c}\text { Callus formation } \\
\text { (\%) }\end{array}$ \\
\hline \multirow[t]{4}{*}{$\overline{B A}$} & 0.1 & & 0 & 0 \\
\hline & 0.5 & & $27 \pm 0.02$ & $50 \pm 0.02$ \\
\hline & 1.5 & & $25 \pm 0.05$ & $65 \pm 0.12$ \\
\hline & 2.0 & & $23 \pm 0.04$ & $53 \pm 0.01$ \\
\hline \multirow[t]{4}{*}{ TDZ } & 0.1 & & $24 \pm 0.02$ & $61 \pm 0.08$ \\
\hline & 0.5 & & $23 \pm 0.01$ & $66 \pm 0.02$ \\
\hline & 1.5 & & $24 \pm 0.02$ & $71 \pm 0.14$ \\
\hline & 2.0 & & $22 \pm 0.13$ & $73 \pm 0.04$ \\
\hline \multirow[t]{4}{*}{ 2,4-D } & 0.1 & & 0 & 0 \\
\hline & 0.5 & & $26 \pm 0.06$ & $43 \pm 0.05$ \\
\hline & 1.5 & & $25 \pm 0.11$ & $40 \pm 0.02$ \\
\hline & 2.0 & & $24 \pm 0.01$ & $57 \pm 0.08$ \\
\hline \multirow[t]{4}{*}{$\mathrm{BA}+\mathrm{NAA}$} & $0.1+0.05$ & & 0 & 0 \\
\hline & $0.5+0.05$ & & $23 \pm 0.13$ & $62 \pm 0.16$ \\
\hline & $1.5+0.05$ & & $21 \pm 0.02$ & $74 \pm 0.08$ \\
\hline & $2.0+0.05$ & & $20 \pm 0.12$ & $68 \pm 0.01$ \\
\hline $2,4-D+N A A$ & $0.1+0.05$ & & 0 & 0 \\
\hline
\end{tabular}




\begin{tabular}{|c|c|c|c|}
\hline \multirow{6}{*}{$\mathrm{TDZ}+\mathrm{NAA}$} & $0.5+0.05$ & $23 \pm 0.13$ & $48 \pm 0.06$ \\
\hline & $1.5+0.05$ & $23 \pm 0.05$ & $56 \pm 0.12$ \\
\hline & $2.0+0.05$ & $22 \pm 0.13$ & $64 \pm 0.04$ \\
\hline & $0.1+0.05$ & $21 \pm 0.04$ & $65 \pm 0.06$ \\
\hline & $1.5+0.05$ & $25 \pm 0.06$ & $83 \pm 0.14$ \\
\hline & $2.0+0.05$ & $20 \pm 0.11$ & $74 \pm 0.18$ \\
\hline
\end{tabular}

Values are expressed as Mean \pm Standard Error of 3 replicates. Means within a column followed by a common letter aren’t significantly different at $5 \%$ level by SPSS.

\section{REFERENCES}

Adhikari, B.S., M.M. Babu, P.L. Saklani and G.S Rawat, (2010). Medicinal Plants Diversity and their Conservation Status in Wildlife Institute of India (WII) Campus, Dehradun. Ethnobotanical Leaflets 14: 46-83.

Aditi Singh, S., K. Sah, A. Pradhan, S. Rajbahak and N. Maharaja, (2009). In vitro study of Tinospora cordifolia (Willd.) Miers (Menispermaceae). Botanica Orientalis J. Plant Sci. 6: 103-105.

Ananthi, P., B.D. Ranjitha Kumari and A. Ramachandran, (2011). In vitro propagation of Rorippa indica L. from nodaland shoot tip explants. Inter. J. Biotechnol. Molecular Biol. Res. 2(3) 51-55.

Bapat, V.A., S.R. Yadav and G.B. Dixit, (2008). Rescue of endangered plants through biotechnological applications. National Academy Sci. Letters, 31: 201210.

Baskar, P. and N. Jayabalan, (2005). An efficient micropropagation system for Eclipta alba a valuable medicinal herb. In Vitro Cellular and Develop. Biol. Plant. 41(4): 532-539.

of Sourthern India. Plant Tissue Cult. Biotechnol. 17(2): 115-124.

Kayser, O., and W.J. Quax, (2007). Medicinal Plant Biotechnology. From Basic Research to Industrial Applications. WILEY-VCH Verlag GmbH \& Co. KGaA, Weinheim.

Khatun, A., S. Nasrin and M.T. Hossain, (2003). Large scale multiplication of ginger (Zingiber Officinale Rosc.) from shoot-tip culture. J. Biological Sci. 3: 59-64.

Kuo, P.L., Y.L. Hsu, T.C. Lin, L.T. Lin, J.K. Chang and C.C. Lin, (2005). Induction of cell cycle arrest and apoptosis in human non-small cell lung cancer A549 cells by casuarinin from the bark of Terminalia arjuna Linn. Anticancer Drugs, 16: 409-415.

Mallon, R., J. Rodriguez-Oubina, and M.L. Gonzalez, (2010). In vitro propagation of the endangered plant Centaurea ultreiae: assessment of genetic stability by cytological studies, flow cytometry and RAPD analysis. Plant Cell Tiss. Org. 101: 31-39.

Mariani, T.S., A. Fitriani, J.A. Teixeira da Silva, A. Wicaksono. And T.F. Chia, (2011). Micropropagation of Aglaonemausing axillary shoot explants. Inter. J. Basic and Appl. Sci. 11(1):46-53.

Martin, K.P. (2002). Rapid propagation of Holostema adakodien Schult. a rare medicinal plant, through axillary bud multiplication and indirect organogenesis. Plant Cell. Rep. 21: 112-117.
Bramwell, D. (1990). The Role of in vitro cultivation in the conservation of endangered species. Conservation Techniques in Botanic Gardens - Koeningstein, Germany, Koeltz Scientific Books.

Chand, S. and S.C. Roy, (1980). Effect of different auxins on chromosome behaviour of leaf callus tissues of Nigela sativa. Caryologia 33:387-392.

Fnaec, (2002). Flora of North America editorial committee. Flora of North America North of Mexico 26: 14-46.

Fraternale, D., L. Giamperi, D. Ricci and M.B.L. Rocchi, (2002). Micropropagation of Bupleurm fruticosum: The effect of triacontanol. Plant Cell, Tissue and Organ Cult. 69: 135-140.

Kannan, P., A. Premkumar and S. Ignacimuthu, (2007). Thidiazuron induced shoot regeneration in the endangered species, Exacum travancoricum Beedi. Indian J. Biotech. 6: 564-566.

Karuppusamy, S. and T. Pullaiah, (2007). In vitro shoot multiplication of Bupleurum distichophyllum Wight.-A native medicinal plant

Paulsamy, S., P. Senthilkumar and M. Shivashanmugam, (2008). Clonal multiplication strategies for medicinal plants inhabiting Nilgiri Biosphere Reserve, the Western Ghats, India. J. Theoret. Experiment. Biol. 4(3):115-119.

Pradeep Kumar, S. and B.D. Ranjitha Kumari, (2010). Effect of Amino Acids and Growth Regulators on Indirect Organogenesis in Artemisia vulgaris L. Asian J. Biotechnol. 1-9.

Sahooy, Pattnaik, S.K. and P.K. Chand, (1997). In vitro clonal propagation of an aromatic medicinal herb Ocimum basilicum L. (sweet basil) by axillary shoot proliferation. In Vitro Cell. Development. Biol. - Plant 33: 293-296.

Skoog, F. and C.O. Miller, (1957). Chemical regulation of growth and organ formation in plant tissue cultures in vitro. Symp. Soc. Exp. Biol. 11: 118-131.

Sujatha, G., B.D. Ranjitha Kumari, P.L. Cioni, and G. Flamini, (2008). Mass propagation and essential oil analysis of Artmeisia vulgaris. J. Biosci. Bioengineer. 105(3): 176183.

Vidya, S.M., V. Krishna, B.K. Manjunath and Shankarmurthy (2005). Micro propagation of Entada pursaetha DC-An endangered Medicinal plant of Western Ghats. Indian. J. Biotech. 4: 561-564. 